\title{
MAC: uma coleção contemporânea
}

\section{LISBETH REBOLLO GONÇALVES}

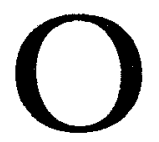

Museu de Arte Contemporânea foi criado em 1963, quando a Universidade de São Paulo, na gestáo do reitor Ulhôa Cintra, recebeu de Francisco Matarazzo Sobrinho, então presidente do Museu de Arte Moderna de São Paulo, o acervo que constituía o MAM.

Nos documentos de transferência do acervo para a USP consta a data de 8 de fevereiro, mas o início das atividades do MAC se dá dois meses depois, no dia 8 de abril. O Museu de Arte Contemporânea da USP tem, pois, como herança, a história da constituição da primeira coleção especializada em arte do século XX na América Latina.

$\mathrm{Na}$ história de nosso Museu não houve qualquer participação do Estado, nenhuma política de ação efetiva de teor público, embora se possa visualizar na experiência do Departamento de Cultura - criado em 1935, no município de Sáo Paulo, através do projeto intelectual de personalidades como Paulo Duarte, Mário de Andrade, Sérgio Milliet, entre outros - uma primeira tomada de consciência da necessidade de uma ação organizada voltada para a arte moderna. Pensava-se um modelo de Museu que produzisse a formaçăo e a informaçáo atualizada do conhecimento artístico contemporâneo.

Como todo o acervo museológico, o do MAC-USP se constrói dentro da realidade histórica. Portanto, seu perfil é circunstanciado por valores em torno dos quais fluem a mentalidade de nossa vida intelectual, de nosso processo de modernização social, das características de nossa modernidade.

O perfil da coleçáo originária do MAC permite-nos situar a presença de um padrão histórico de produção e recepçáo da arte nitidamente delimitado e demarcado pela relação Europa-Brasil, nucleado em forma de aspectos ou de artistas dos principais movimentos da primeira metade do século.

Num segundo momento, outro fator constitui alavanca para a formação do acervo, garantindo de alguma maneira sua atualização em termos de contemporaneidade. Trata-se da açáo institucional da Bienal de São Paulo. 
Ao longo dos seus primeiros dez anos de existência, de 1951 a 1961, a Bienal de São Paulo é um evento internacional do MAM; depois, por intermédio da própria Bienal, quer através dos prêmios de aquisição, quer por doaçốes individuais dos artistas que a ela comparecem, a coleção do MAC se enriquece com a presença de nomes que se destacam no cenário artístico mundial.

Ao longo de seus 31 anos de atividades na USP, pela interveniência de seus diretores e a duras penas, o MAC procura garantir esta dinâmica, embora se vá defasando a representatividade do contempordneo.

Integrando a USP, o MAC possui um privilégio, um diferencial importante: o de poder estar em interação viva com a pesquisa científica, tecnológica e cultural que se constrói na mais importante universidade brasileira.

Hoje, seu acervo possui 5362 obras, entre óleos, desenhos, gravuras, esculturas, objetos e obras conceituais, o que o coloca como um museu muito importante, mesmo no cenário internacional.

Lisbeth Rebollo Gonçalpes é diretora do Museu de Arte Contemporânea da USP. 